TITLE:

\title{
Three-dimensional imaging of cystoid macular edema in retinal vein occlusion(Abstract_要旨 )
}

\author{
AUTHOR(S): \\ Yamaike, Noritatsu
}

\section{CITATION:}

Yamaike, Noritatsu. Three-dimensional imaging of cystoid macular edema in retinal vein occlusion. 京都大学, 2008, 博士(医学)

ISSUE DATE:

2008-03-24

URL:

http://hdl.handle.net/2433/135852

RIGHT: 
氏 名山池紀瓶

学位 (専攻分野) 博士 (医学)

学位記番号医 博 第 3232 号

学位授与の日付 平成 20 年 3 月 24 日

学位授与の要件 学 位 規 則 第 4 条第 1 項 該 当

研究科. 専攻医学研究科外科系専攻

学位論文題目 Three-dimensional imaging of cystoid macular edema in retinal vein occlusion

(網膜静脈閉塞症に伴う襄胞様黄斑浮腫の三次元画像化)

論文調査委員教主授福山秀直教授富樫か招り教授伊藤壽一

\section{論文内容の要旨}

\section{【目的】}

高齢者の発症が多いとされている網膜静脈閉塞症（網膜中心静脈閉塞症、網膜静脈分枝閉塞症）においては、しばしば囊胞 様黄斑浮腫を合併し重篤な視力障害を引き起こす。近年、光干渉断層計を用いることによりこの囊胞様黄斑浮腫の詳細な観 察が可能となっている。また、フーリエドメイン光干渉断層計（FD-OCT）により網膜断層撮影の高速化、高感度化がもた らされ、囊胞様黄斑浮腫の三次元画像化が可能となった。FD-OCT を用いて網膜静脈閉塞症に伴う囊胞様黄斑浮腫の三次元 画像化を行い、その有用性について検討した。

\section{【方法】}

スペクトロメーターを用いた FD-OCT システムを無散瞳眼底カメラに組み込み、研究用プロトタイプ FD-OCT を作製した。 プロトタイプ FD-OCT を用いて網膜静脈閉塞症 20 例 20 眼（網膜中心静脈閉塞症 7 眼、網膜静脈分枝閉塞症 13 眼）の囊胞 様黄斑浮腫の詳細な観察を行った。網膜断層像は中心窩を含む $2.8 \mathrm{~mm} \times 2.8 \mathrm{~mm}$ の範囲で水平方向 256 本、垂直方向 256 本 のA スキャンを分配し構築した。

\section{【結果】}

FD-OCT にて網膜の層構造（神経繊維層、神経節細胞層、内網状層、内顆粒層、外網状層、外顆粒層）が明瞭に観察された。 囊胞椂腔は主に内顆粒層（16 眼、80\%)、外網状層（17 眼、85\%）で観察されたが、その他の層でも囊胞様腔は観察された。 FD-OCT にて 20 眼中 18 眼で外境界膜ラインが観察された。そのうち、9 眼（50\%）では囊胞様腔と外境界膜ラインが接し ていた。 7 眼 $(38 \%)$ では囊胞様腔が外境界膜ラインに達していなかった。2 眼 (11\%) では震胞様腔下で外境界膜ラインが 途絶していた。囊胞様腔が外境界膜ラインに達していない症例では黄斑部網膜厚に影響されずに視力が良い傾向が認められ た。

\section{【考察】}

FD-OCT による三次元画像化により、網膜静脈閉塞症に伴う囊胞様黄斑浮腫を立体的に観察、評価することが可能であった。 また、囊胞様腔の分布及び進展範囲を観察可能であった。FD-OCTにより可視化された外境界膜ラインの詳細な観察により 網膜静脈閉塞症に伴う囊胞様黄斑浮腫の視力予後予測の可能性が示唆された。

\section{論 文 審 査 の 結 果 の 要 旨}

網膜静脈閉塞症（網膜中心静脈閉塞症、網膜静脈分枝閉塞症）は、しばしば囊胞様黄斑浮腫（CME）を合併し重篤な視力 障害を引き起こすが、有効な検查方法は限られていた。近年、光干渉断層計（OCT）を用いることによりこの CME の詳細な 観察が可能となってきている。スペルトロメーターを用いたフーリエドメイン OCT（FD-OCT）システムを無散瞳眼底カメ ラに組み込み、プロトタイプ FD-OCT を作製した。プロトタイプ FD-OCT を用いて網膜静脈閉塞症 20 例 20 眼（網膜中心静 
脈閉塞症 7 眼、網膜静脈分枝閉塞症 13 眼）の CME の詳細な観察を行った。FD-OCT による CME の観察では、網膜の層構 造が明瞭に観察された。傍中心窩では、囊胞様腔は主に内顆粒層（16 眼、80\%)、外網状層（17 眼、85\%）で観察された。 FD-OCT にて 20 眼中 18 眼（90\%）で外境界膜ラインが観察された。そのうち、9眼（50\%）では囊胞様腔と外境界膜ライ ンが接していた。 7 眼（38\%）では囊胞様腔が外境界膜ラインに達していなかった。2 眼（11\%）では囊胞様腔下で外境界 膜ラインが途絶していた。囊胞様腔が外境界膜ラインに達していない症例では、黄斑部網膜厚に影響されずに視力が良い傾 向が認められた。以上から申請者は網膜静脈閉塞症に伴う CME の三次元画像化による画像解析が、CME の形態評価、視機 能評価に有効であることを示した。

以上の研究は、網膜静脈閉塞症に伴う囊胞様黄斑浮腫の構造解明に寄与するところが多い。

したがって、本論文は博士（医学）の学位論文として価値あるあのと認める。

な打、本学位授与申請者は、平成 20 年 3 月 5 日実施の論文内容とそ机に関連した試問を受け、合格と認めら杖むので ある。 